\begin{tabular}{|c|l|}
\hline Title & $\begin{array}{l}\text { Specific inhibitor and substrate specificity of alkaline phosphatase expressed in the symbiotic phase of the arbuscular } \\
\text { mycorrhizal fungus, Glomus etunicatum }\end{array}$ \\
\hline Author(s) & Ezawa, Tatsuhiro; Kuwahara, Shin-ya; Sakamoto, Kazunori; Y oshida, Tomio; Saito, Masanori \\
\hline Citation & $\begin{array}{l}\text { Mycologia, 91(4), 636-641 } \\
\text { https:/doi.org/10.2307/3761249 }\end{array}$ \\
\hline Issue Date & 1999-07 \\
\hline Doc URL & http://hdl.handle.net/2115/38843 \\
\hline Rights & ○ 1999 The Mycological Society of A merica \\
\hline Type & article \\
\hline File Information & ezawa.pdf \\
\hline
\end{tabular}

Instructions for use 


\section{Specific inhibitor and substrate specificity of alkaline phosphatase expressed in the symbiotic phase of the arbuscular mycorrhizal fungus, Glomus etunicatum}

\author{
Tatsuhiro Ezawa ${ }^{1}$ \\ University Farm, School of Agricultural Science, \\ Nagoya University, Togo-cho, Aichi 470-01 Japan
}

Shin-ya Kuwahara

Kazunori Sakamoto

Tomio Yoshida

Faculty of Horticulture, Chiba University, Matsudo, Chiba 271 Japan

Masanori Saito

National Grassland Research Institute, Nishinasuno, Tochigi 329-27 Japan

\begin{abstract}
Specific inhibitor and substrate specificity of alkaline phosphatase in the arbuscule of Glomus etunicatum were investigated, and the possible role of this enzyme in the symbiosis was discussed. Mycorrhizal roots of marigold (Tagetes patula) were digested by cellulase and pectinase to separate the intraradical hyphae from the root tissue, and phosphatase activity was stained at $\mathrm{pH} 8.5$ and 5.0. The activity of alkaline phosphatase ( $\mathrm{pH} 8.5$ ) in arbuscules was inhibited in the presence of beryllium, whereas that of acid phosphatase ( $\mathrm{pH}$ 5.0) was less sensitive to beryllium. Specificity and effectiveness of beryllium on the alkaline phosphatase was further confirmed using fractionated (soluble and insoluble) enzyme prepared from the separated hyphae. The soluble and insoluble alkaline phosphatases hydrolyzed phosphomonoester compounds (glucose-6-phosphate, $\beta$-glycerophosphate, trehalose-6-phosphate and glucose 1phosphate) but not pyrophosphate compounds (ATP and polyphosphate) which were hydrolyzed by acid phosphatase efficiently. The insoluble alkaline phosphatase showed high specific activity (on a protein basis) and high sensitivity to beryllium. Kinetic analysis of the insoluble alkaline phosphatase suggested the involvement of this enzyme in the sugar metabolism of the fungus due to lower $\mathrm{Km}$ values for sugar phosphate such as glucose-6-phosphate and trehalose-6-phosphate.
\end{abstract}

Key Words: beryllium, enzyme, sugar phosphate

Accepted for publication February 5, 1999.

${ }^{1}$ Present address: Dept. of Soil Science, Waite Agricultural Research Institute, University of Adelaide, Glen Osmond 5064 SA, Australia. Email: tezawa(a) waite.adelaide.edu.au

\section{INTRODUCTION}

The arbuscule is a distinctive organ formed in arbuscular mycorrhizas. It is supposed that the arbuscular interface is the site of phosphate transfer from the fungus to the host, because $\mathrm{H}^{+}$-ATPase activity coupled phosphate uptake would be associated at the periarbuscular membrane (Gianinazzi-Pearson et al 1991, Smith and Read 1997). Alkaline phosphatase (ALPase) in arbuscular mycorrhizal fungi is an enzyme specific to the symbiotic status (Saito 1995) and localized at fine structural (mature) arbuscules (Ezawa et al 1995, Gianinazzi et al 1979), and this contrasts with acid phosphatase (ACPase) which was active both at the symbiotic and nonsymbiotic phases (Macdonald and Lewis 1978, Saito 1995). Because of the specific localization the involvement of ALPase in phosphate transfer has been suggested (GianinazziPearson and Gianinazzi 1983, Guillemin et al 1995, Tisserant et al 1993). The characteristics of ALPase, however, are not well understood, although it is essential to understanding the metabolic role of this enzyme.

Crude enzyme preparations or tissue of mycorrhizal roots were used in past studies on mycorrhizal phosphatases. However, several phosphatases, such as nonspecific phosphatases (Ezawa et al 1995, Gianinazzi et al 1979, Gianinazzi-Pearson and Gianinazzi 1978, Saito 1995), neutral phosphatase (Jeanmaire et al 1985), ATPases (Gianinazzi-Pearson et al 1991, McArthur and Knowles 1993) and polyphosphatases (Capaccio and Callow 1982), could be associated with those preparations, and this made it unclear which phosphatase would be responsible to the activity. A specific inhibitor is useful to identify the activity of specific enzyme. Cyanide $\left(\mathrm{CN}^{-}\right)$was used as an specific inhibitor for the mycorrhizal alkaline phosphatase (Gianinazzi-Pearson and Gianinazzi 1978, Tisserant et al 1993) but did not inhibit the activity in the intact hyphae of Glomus etunicatum, G. mosseae and Gigaspora rosea (Ezawa et al 1995). Beryllium (Be ${ }^{2+}$ ) is known as a specific inhibitor of animal and bacterial ALPases (Klemperer et al 1949, Thomas and Aldridge 1966) and 1000-fold as strong as those of metal chelators such as cyanide and EDTA (Bell 1972, Thomas and Aldridge 1966).

In this study, the intraradical hyphae of Glomus etunicatum were separated from the roots by the en- 
zymatic digestion technique, and specificity and effectiveness of $\mathrm{Be}^{2+}$ on the alkaline phosphatase in the hyphae were demonstrated. Furthermore, substrate specificity of the enzyme was investigated based upon the specific inhibition with $\mathrm{Be}^{2+}$.

\section{MATERIALS AND METHODS}

Separation of intraradical hyphae.-Dwarf marigold (Tagetes patula $\mathrm{cv}$. Bonanza Spray) was inoculated with Glomus etunicatum and cultured in a growth chamber as described by Ezawa and Yoshida (1994). Mycorrhizal roots were harvested 6 wk after sowing, cut into 5-10 mm segments, incubated at $30 \mathrm{C}$ for $60 \mathrm{~min}$ in a 10-fold vol (w:vol) of $20 \mathrm{~g} \mathrm{~L}^{-1}$ Cellulase Onozuka RS (Yakult Pharmaceutical Ind., Tokyo), $20 \mathrm{~g} \mathrm{~L}^{-1}$ Driselase (Kyowa Hakko Kogyo, Tokyo) and $10 \mathrm{~g}$ $\mathrm{L}^{-1}$ Pectolyase Y-23 (Seishin Corp., Tokyo) in $10 \mathrm{mM} \mathrm{MES/}$ $\mathrm{NaOH}(\mathrm{pH} 5.5)$ and washed in washing buffer $(1 \mathrm{mM}$ dithiothreitol, $0.3 \mathrm{M}$ mannitol, $10 \mathrm{mM}$ Tris/ $\mathrm{HCl}, \mathrm{pH}$ 7.6) at $0 \mathrm{C}$ (Ezawa et al 1995). The root cortex became translucent at this step. And colonized roots were selected under a dissecting microscope.

Histochemical study.-The cortex of digested roots was torn with needles to expose the fungal tissue. Phosphatase activity in the hyphae was visualized by the azo dye method (Scandalios 1969). The fungal tissue was preincubated for $30 \mathrm{~min}$ at $35 \mathrm{C}$ in the preincubation solution ( $100 \mathrm{mM}$ Tris/ $\mathrm{HCl}$ buffer $\mathrm{pH} 8.5$ or $100 \mathrm{mM}$ acetate buffer $\mathrm{pH} 5.0$ ) with or without $1 \mathrm{mM} \mathrm{BeSO}_{4}$, then transferred to the staining medium ( $4 \mathrm{mM} \alpha$-naphtyl acid phosphate (substrate), $1 \mathrm{~g}$ $\mathrm{L}^{-1}$ Fast Blue RR salt (azo dye) in $100 \mathrm{mM}$ Tris/ $\mathrm{HCl}$ buffer or $100 \mathrm{mM}$ acetate buffer) with or without $1 \mathrm{mM} \mathrm{BeSO}$ and incubated at $35 \mathrm{C}$ for $120 \mathrm{~min}$.

After staining, the specimens were transferred to lactoglycerol and mounted on glass slides. The numbers of arbuscules showing phosphatase activity (indicated by black precipitation) per unit length $(200 \mu \mathrm{m})$ of colonized root were measured at $\times 100-200$. The measurements were made at five different positions per root segment, and at least 10 segments were observed for each treatment.

Fractionation of hyphal enzyme.-Intraradical hyphae were collected from the digested roots with fine needles under a dissecting microscope, weighed and stored in a $1.5 \mathrm{~mL}$ microtube at $-85 \mathrm{C}$.

Two to four mg (FW) of the fungal tissue was ground in a small mortar (6 cm diam) with 10-fold vol (w:vol) of the extraction buffer $(0.88 \mathrm{M}$ sucrose in $100 \mathrm{mM}$ Tris $/ \mathrm{HCl} \mathrm{pH}$ 7.5 ) at $0 \mathrm{C}$. The slurry was transferred to a $1.5-\mathrm{mL}$ microtube. The mortar and pestle were washed with the same vol of extraction buffer. The solutions were combined and centrifuged at $10000 \mathrm{~g}$ for $10 \mathrm{~min}$ at $4 \mathrm{G}$, and the residue was resuspended in a 20 -fold vol of the buffer and centrifuged. The supernatants were combined and the volume was adjusted to 100-fold vol of the original weight with the buffer (soluble fraction). The residue was washed twice in the buffer and suspended in 100-fold vol of the buffer (insoluble fraction).
TABLE I. Influence of beryllium on the frequency of arbuscules showing activity of phosphatase of Glomus etunicatum

\begin{tabular}{|c|c|c|}
\hline \multirow[b]{2}{*}{$\mathrm{pH}$} & \multicolumn{2}{|c|}{ Active arbuscules $/ 200 \mu \mathrm{m}$} \\
\hline & Control & $1 \mathrm{mM} \mathrm{BeSO}_{4}$ \\
\hline 8.5 & $12.3 \pm 1.8^{\mathrm{a}}(100)^{\mathrm{b}}$ & $0.2 \pm 0.1(1.6)$ \\
\hline 5.0 & $9.8 \pm 1.4(100)$ & $7.1 \pm 0.4(72.5)$ \\
\hline
\end{tabular}

${ }^{a} \pm \operatorname{SE}(n=10)$

b Values in parentheses indicate the percentage of active arbuscules relative to the control.

Inhibitors and substrates.-ALPase inhibitors used were $\mathrm{BeSO}_{4}, \mathrm{KCN}$, ethylenediaminetetraacetic acid (EDTA) (Bell 1972) and $\mathrm{Na}_{2} \mathrm{MoO}_{4}$ (Gianinazzi-Pearson et al 1991, McArthur and Knowles 1993). Acid phosphatase (ACPase) inhibitors used were $\mathrm{BeSO}_{4}, \mathrm{Na}_{2} \mathrm{MoO}_{4}$ and $\mathrm{NaF}$ (Arnold et al 1987). All these inhibitors were purchased from Wako Pure Chemical, Japan.

All substrates for phosphatase assays were purchased from Sigma Chemical Co. Polyphosphate ranging in chain-length from 90 to 190 was prepared by electrophoresis as described by Clark and Wood (1987). Polyphosphate Type $75+$ was dissolved in electrophoresis buffer and loaded on a $10 \%$ polyacrylamide gel. After electrophoresis, the gel between the two tracking dyes, bromophenol blue and xylene cyanol, was cut and polyphosphate in the gel piece was extracted and concentrated. Polyphosphate in the extraradical hyphae of $G$. etunicatum was extracted, treated with ribonuclease (Wako Pure Chemical, Japan) for 30 min at 55 $\mathrm{C}$ and electrophoresed (Clark et al 1986) to check the suitability of the prepared polyphosphate as substrate for the fungal enzyme. The authors considered the prepared polyphosphate to be an appropriate substrate for the assessment of polyphosphate-hydrolyzing activity in the fungus, because the range of chain length of fungal polyphosphate was much broader than that of the prepared polyphosphate.

Enzyme assay conditions. - Extract $(20-40 \mu \mathrm{L}$ containing the soluble or insoluble enzyme from $0.2-0.4 \mathrm{mg}$ hyphae) and substrate were incubated in $100 \mathrm{mM}$ Tris/ $\mathrm{HCl}$ buffer $\mathrm{pH}$ 8.5 or $100 \mathrm{mM}$ acetate buffer $\mathrm{pH} 5.0$ with or without phosphatase inhibitor in $400 \mu \mathrm{L}$ total vol at $35 \mathrm{C}$ for $90 \mathrm{~min}$ [for $p$-nitrophenylphosphate (NPP) as substrate] or 120 min (for other substrate). After the incubation, the reaction mixtures of insoluble fraction were centrifuged immediately, and $360 \mu \mathrm{L}$ of supernatant was transferred to a new tube. Insoluble materials in the tube were reserved to measure protein concentration. The reaction was terminated by adding $0.25 \mathrm{vol}$ of $1 \mathrm{M} \mathrm{NaOH}$ (final concentration was $0.2 \mathrm{M}$, in the case of NPP) or a $0.67 \mathrm{vol}$ of $\mathrm{FeSO}_{4}\left(\mathrm{NH}_{4}\right)_{2} \mathrm{MoO}_{4}$ reagent (in the case of other substrate) (Taussky and Shorr 1953). The activity of phosphatase was determined by the absorbance of $p$-nitrophenol at $410 \mathrm{~nm}$ or the amount of inorganic phosphate released (Taussky and Shorr 1953). Under these conditions, the formation of product showed a linear relation with time. Protein concentration in the soluble fraction was determined by the method of Bradford 

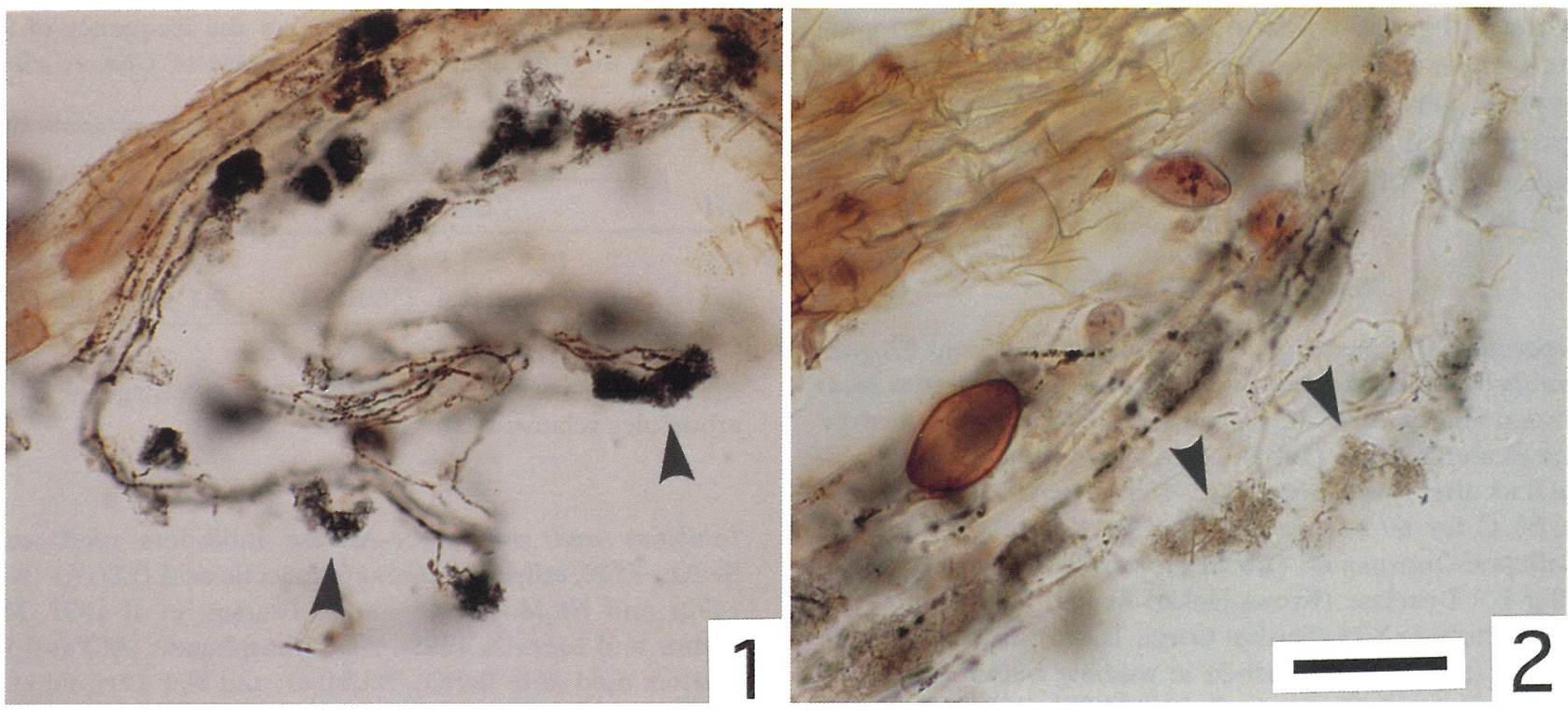

FIGs. 1, 2. Inhibition of alkaline phosphatase activity in the arbuscules (arrow heads) of Glomus etunicatum by beryllium. Phosphatase activity was indicated by black precipitation. 1. Control. 2. Stained in the presence of $1 \mathrm{mM} \mathrm{BeSO}_{4}$. $\mathrm{Bar}^{2} 40 \mu \mathrm{m}$.

(1976). Protein concentration in the insoluble fraction was determined as follows. Insoluble materials remaining in the reaction tubes were combined (10-15 tubes into one), and an equal vol of $10 \%$ trichloroacetic acid was added. After incubation for $30 \mathrm{~min}$ at $4 \mathrm{C}$, the mixture was centrifuged,

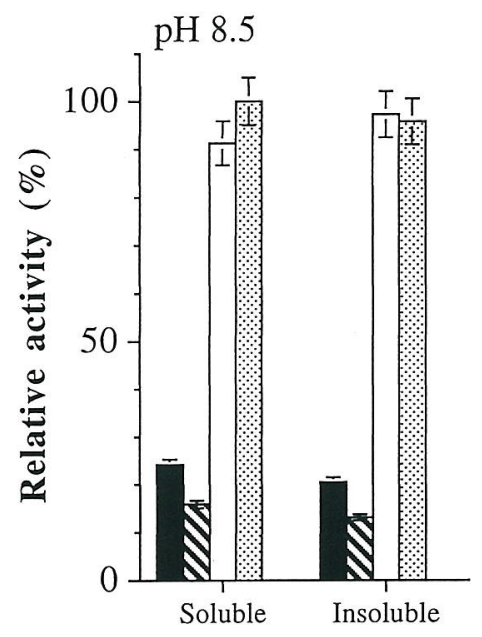

Fraction

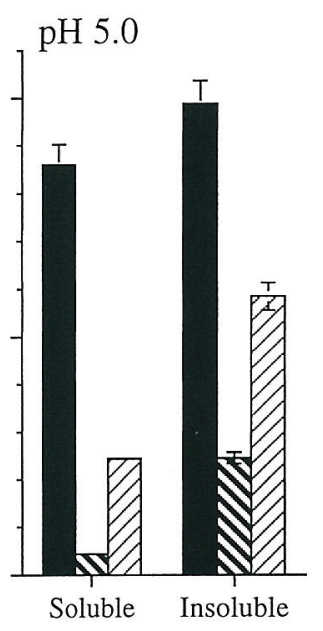

Fraction

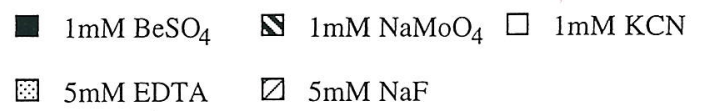

FIG. 3. Effect of various inhibitors on the rerative activities of alkaline $(\mathrm{pH} 8.5)$ and acid $(\mathrm{pH} 5.0)$ phosphatases in the soluble and insoluble fractions of the intraradical hyphae of Glomus etunicatum. Phosphatase activities are expressed by percentage relative to the control $(100 \%)$. The activity was measured by the absorbance of $p$-nitrophenol at $410 \mathrm{~nm}$ using $20 \mu \mathrm{L}$ enzyme solution and $4 \mathrm{mM}$-nitrophenylphosphate as a substrate. Vertical bars mean SE $(n=3)$. and the supernatant was discarded. Protein in the residue was extracted by $50 \mu \mathrm{L}$ of $1 \mathrm{~N} \mathrm{NaOH}$ and quantified as described by Lowry et al (1951) because the method of Bradford (1976) could not be applied to the alkaline samples. One unit (U) of phosphatase activity was defined as the amount of enzyme which released $1 \mathrm{nmol}$ of orthophosphate per min under the specific conditions. Kinetic parameters were determined by the statistical method described by Wilkinson (1961).

\section{RESULTS}

Specific inhibition.-The inhibitory effect of $\mathrm{Be}^{2+}$ on phosphatase activities in arbuscules was examined at pH 8.5 (ALPase) and 5.0 (ACPase) histochemically and found to be specific to ALPase. The number of arbuscules showing phosphatase activity was greatly reduced in the presence of $\mathrm{Be}^{2+}$ at $\mathrm{pH} 8.5$ (TABLE I, FIGS. 1, 2). In contrast, the effect of $\mathrm{Be}^{2+}$ on the activity in arbuscules at pH 5.0 was limited (TABLE I).

The effects of various inhibitors on the activity of fractionated enzymes at $\mathrm{pH} 8.5$ and 5.0 were compared using NPP as substrate, and the effectiveness and specificity of $\mathrm{Be}^{2+}$ on the activity of ALPase was confirmed. $\mathrm{Be}^{2+}$ and molybdate $\left(\mathrm{MoO}_{4}{ }^{2-}\right)$ inhibited the activity in both the fractions strongly at $\mathrm{pH} 8.5$ (FIG. 3), but the metal chelators, EDTA and $\mathrm{CN}^{-}$, did not affect the activities. $\mathrm{Be}^{2+}$ showed no inhibitory effect on the activity at $\mathrm{pH} 5.0$, whereas strong inhibition by $\mathrm{MoO}_{4}{ }^{2-}$ and moderate inhibition by fluoride $\left(\mathrm{F}^{-}\right)$were observed at this $\mathrm{pH}$. Based upon these observations, the authors defined the arbuscular ALPase as beryllium-sensitive activity at $\mathrm{pH} 8.5$, thereafter. 


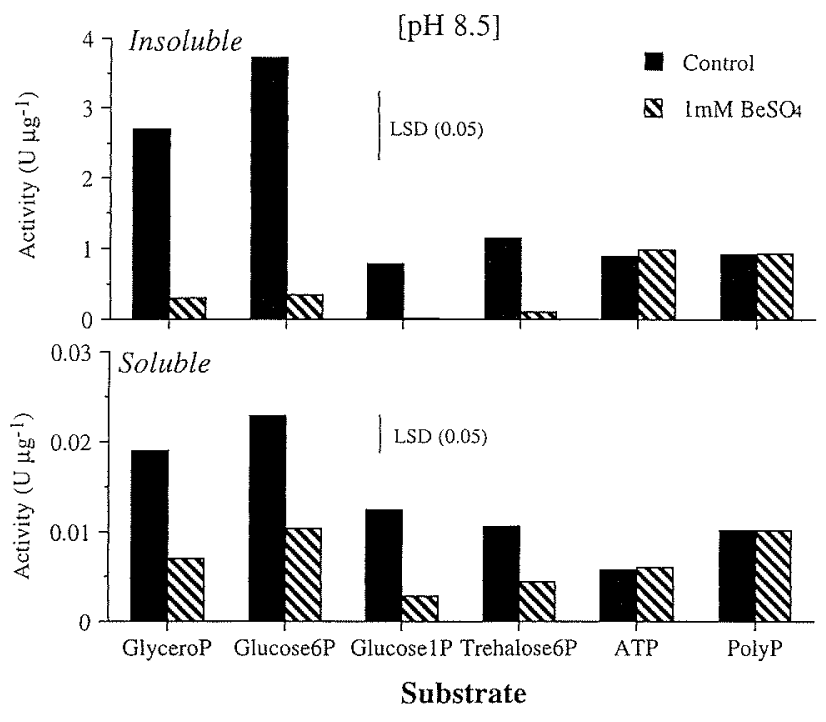

Fig. 4. Alkaline hosphatase activity ( $\mathrm{pH} 8.5)$ of the insoluble and soluble fractions with various substrate in the presence or absence of $1 \mathrm{mM} \mathrm{BeSO}$. The concentration of substrate was $12 \mathrm{mM}$. GlyceroP, $\beta$-glycerophosphate; Glucose6P, glucose-6-phosphate; Glucose1P, glucose-1-phosphate; Trehalose6P, trehalose-6-phosphate; ATP, adenosinetriphosphate; PolyP, polyphosphate.

Substrate specificity.-Rates of hydrolysis of some natural phosphate compounds by ALPase were investigated, being compared with those by ACPase. Glucose-6-phosphate and B-glycerophosphate were hydrolyzed most efficiently by both the soluble and insoluble enzymes at pH 8.5 (FIG. 4). Glucose-1-phosphate, trehalose-6-phosphate, ATP and polyphosphate were also hydrolyzed. The activities with phosphomonoester compounds (glucose-6-phosphate, $\beta$-glycerophosphate, glucose-1-phosphate and trehalose-6phosphate) were inhibited by $\mathrm{Be}^{2+}$, but those with pyrophosphate compounds (ATP and polyphosphate) were not. The sensitivity of the insoluble enzyme to $\mathrm{Be}^{2+}$ was higher ( $80-90 \%$ inhibition) than that of the soluble enzyme (55-77\% inhibition). The specific activity in the insoluble fraction was 100 -fold higher than in the soluble fraction. Substrate specificity of the ACPases ( $\mathrm{pH}$ 5.0) was different from that of the ALPase (FIG. 5). The insoluble enzyme showed a broad substrate specificity although ATP was less preferable. The soluble enzyme hydrolyzed pyrophosphate compounds more efficiently than phosphomonoester compounds.

Because a large part of ALPase activity was associated with the insoluble fraction, kinetic parameters of the insoluble ALPase with some phosphomonoester compounds were determined (TABLE II). The Km values with glucose-6-phosphate and trehalose-6phosphate (1.49 and $1.47 \mathrm{mM}$, respectively) were significantly lower than that of $\beta$-glycerophosphate
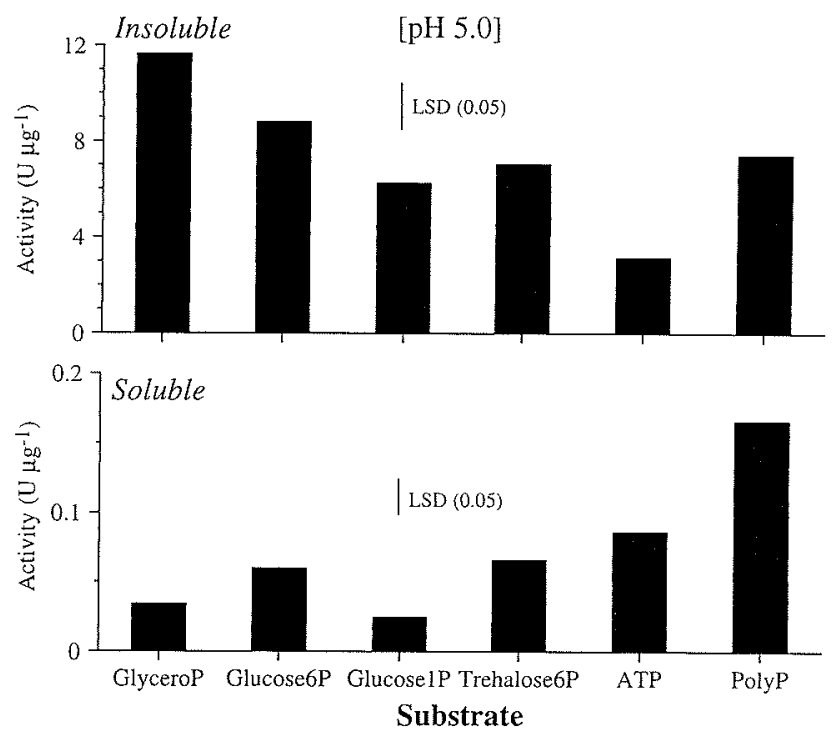

FIG. 5. Acid phosphatase activity (pH 5.0) of the insoluble and soluble fractions with various substrate. The concentration of substrate was $12 \mathrm{mM}$. The abbreviations of substrate were the same as FIG. 4.

(3.35 $\mathrm{mM}$ ). The Vmax values with glucose-6-phosphate (4.10 $\mathrm{U}_{\mu \mathrm{g}^{-1}}$ ) and $\beta$-glycerophosphate (3.91 U $\left.\mu \mathrm{g}^{-1}\right)$ were significantly higher than those of glucose1-phosphate and trehalose-6-phosphate (1.03 and $1.32 \mathrm{U} \mu \mathrm{g}^{-1}$, respectively).

\section{DISCUSSION}

This is the first report demonstrating the characteristics of mycorrhizal ALPase extracted directly from the pure fungal tissue. Characterization of the mycorrhizal ALPase has been reported for the soluble fraction extracted from colonized root tissue based upon electrophoretic analyses (Fabig et al 1989, Gianinazzi-Pearson and Gianinazzi 1976, 1978). It was uncertain, however, if the ALPase originated

TABLE II. Kinetic parameters of alkaline phosphatase in the insoluble fraction of the intraradical hyphae of Glomus etunicatum

\begin{tabular}{lcc}
\hline \multicolumn{1}{c}{ Substrate } & $K \mathrm{~m}(\mathrm{mM})^{\mathrm{a}}$ & $\begin{array}{c}V_{\max } \\
(\mathrm{U} \mu g \\
\left.\text { protein }^{-1}\right)^{\mathrm{a}}\end{array}$ \\
\hline B-glycerophosphate & $3.35 \pm 0.30^{\mathrm{b}}$ & $3.91 \pm 0.94$ \\
glucose-6-phosphate & $1.49 \pm 0.72$ & $4.10 \pm 0.68$ \\
glucose-1-phosphate & $2.22 \pm 1.02$ & $1.03 \pm 0.34$ \\
trehalose-6-phosphate & $1.47 \pm 0.55$ & $1.32 \pm 0.26$ \\
\hline
\end{tabular}

${ }^{a}$ Kinetic parameters were determined at $\mathrm{pH} 8.5$ using a $40 \mu \mathrm{L}$ enzyme solution (corresponding to $0.096 \mu \mathrm{g}$ protein).

$\mathrm{b} \pm \mathrm{SE}$. 
from the host or the fungus in these studies. Recently, a soluble fungal phosphatase from mycorrhizal roots was found to be of intraradical hyphal origin (Kojima et al 1998), but the enzyme has not yet been characterized. The present results also showed that considerable activity of the fungal ALPase was associated with the insoluble fraction. The authors considered that the insoluble ALPase might represent the activity revealed by the histochemical experiment because of the high specific activity (protein basis) and the high sensitivity to beryllium.

The histochemical and biochemical studies showed that the phosphatase activity at $\mathrm{pH} 8.5$ in the arbuscules was inhibited strongly by beryllium, a typical characteristic of nonspecific alkaline phosphatase (ALPase) (E.C. 3.1.3.1) (Klemperer et al 1949, Thomas and Aldridge 1966). Lack of inhibition of acid phosphatase (ACPase) by beryllium was consistent with the observation of Klemperer et al (1949). This indicates that beryllium is a specific inhibitor for ALPase in the arbuscule, and further implies that the activity of this enzyme can be specifically determined in the crude extract containing other phosphatases by using beryllium. As shown by our previous study and the present result, we could not observe an inhibitory effect of cyanide. This is not consistent with the histochemical observations by Gianinazzi-Pearson and Gianinazzi (1978) and Tisserant et al (1993) in which different fungal species were used. Sensitivity of the ALPase of those fungi to cyanide should be confirmed by using enzyme preparations directly extracted from the pure fungal tissue.

The ALPase, unlike the ACPase, showed apparent substrate specificity. Glucose-6-phosphate showed the lowest $\mathrm{Km}$ and highest Vmax, indicating that this compound was the best substrate among the tested compounds for the arbuscular ALPase. Trehalose-6phosphate would also be a good substrate due to a low $\mathrm{Km}$ as that of glucose-6-phosphate. $\beta$-Glycerophosphate was hydrolyzed efficiently at higher concentration $(8-12 \mathrm{mM})$, but the hydrolysis rate decreased considerably below $4 \mathrm{mM}$ (data not shown) as reflected in the highest $\mathrm{Km}$ (TABLE II). The arbuscular ALPase did not hydrolyze pyrophosphate compounds, such as ATP and polyphosphate. Soluble and insoluble (membrane bound) ALPases from $\mathrm{Ba}$ cillus licheniformis also showed low activity with ATP (Hansa et al 1981), whereas extracellular ALPase from Escherichia coli (Reid and Wilson 1971) and Neurospora crassa (Say et al 1996) hydrolyzed ATP. Difference in catalytic activity between intra- and extracellular ALPases could be an indication of functional differentiation. Higher rate of hydrolysis of polyphosphate at $\mathrm{pH} 5.0$ by the soluble enzyme was observed. Not only ACPase but also exopolyphospha- tase might be involved (Capaccio and Callow 1982, Ezawa and Saito unpubl).

In the symbiotic phase, the intraradical hyphae of arbuscular mycorrhizal fungi may take up glucose as an energy source (Shachar-Hill et al 1995, Solaiman and Saito 1997). Glucose-6-phosphate can be generated by the phosphorylation of glucose by hexokinase (Saito 1995) and/or polyphosphateglucokinase (Capaccio and Callow 1982, Ezawa and Saito unpubl) in the hyphae. Glucose-6-phosphate itself is a key compound of many important metabolic pathways in the fungi such as the pentose monophosphate cycle (Saito 1995) and the biosynthesis of trehalose (Schubert et al 1992, Shachar-Hill et al 1995) and glycogen (Shachar-Hill et al 1995). Trehalose-6-phosphate, an intermediary metabolite of trehalose biosynthesis, should be synthesized by trehalose-6-phosphate synthase from glucose-6-phosphate and UDP-glucose. It is suggested that the ALPase may be involved in the metabolism of these sugar phosphates.

Tisserant et al (1993) used ALPase activity as an index of phosphate translocation from the fungus to the host, suggesting a function of the ALPase such as a membrane transporter of inorganic phosphate. Conversely, Larsen et al (1996) found no correlation between phosphate translocation of the fungus and ALPase activity, because fungicide (benomyl) application inhibited fungal phosphate translocation but not ALPase activity in the hyphae. As they pointed out, however, the benomyl-mediated inhibition occurred in the extraradical hyphae which was far from the arbuscular interface. Assuming the possible role of the ALPase in the phosphate transfer, it is hypothesized that a part of phosphate released into the interfacial apoplast may be provided by the ALPase via the hydrolysis of intermediary metabolites such as sugar phosphates. Further studies focused on carbon and (poly) phosphate metabolism are required to examine this hypothesis.

\section{ACKNOWLEDGMENTS}

We thank Dr. M. Maeshima for his invaluable suggestion and Dr. C. Walker for his critical reading of this manuscript. This work was partly supported by Grants-in-Aid from The Ministry of Education, Science, Sports and Culture (T.E.) and The Ministry of Agriculture, Forestry and Fisheries (BMP 96-V-1) (M.S.), Japan.

\section{LITERATURE CITED}

Arnold WN, Sakai KH, Mann LC. 1987. Selective inactivation of an extra-cytoplasmic acid phosphatase of yeastlike cells of Sporothix schenckii by sodium fluoride. J Gen Microbiol 133:1503-1509.

Bell HV. 1972. Kinetics and inhibition of alkaline phospha- 
tases from canine tissues. Biochim Biophys Acta 289: 158-168.

Bradford MM. 1976. A rapid and sensitive method for the quantitation of microgram quantities of protein utilizing the principle of protein-dye binding. Anal Biochem $72: 248-254$.

Capaccio LCM, Callow JA. 1982. The enzymes of polyphosphate metabolism in vesicular-arbuscular mycorrhizas. New Phytol 91:81-91.

Clark JE, Beegen H, Wood HG. 1986. Isolation of intact chain of polyphosphate from Propionibacterium shermanii grown on glucose or lactate. J Bacteriol 168: 1212-1219.

- Wood HG. 1987. Preparation of standards and determination of sizes of long-chain polyphosphates by gel electrophoresis. Anal Biochem 161:280-290.

Ezawa T, Saito M, Yoshida T. 1995. Comparison of phosphatase localization in the intraradical hyphae of arbuscular mycorrhizal fungi Glomus spp. and Gigaspora spp. PI Soil 176:57-63.

— Yoshida T. 1994. Acid phosphatase specific to arbuscular mycorrhizal infection in marigold and possible role in symbiosis. Soil Sci PI Nutr 40:655-665.

Fabig B, Moawad AM, Achtnich W. 1989. Gas-chromatographic separation of organic acids and electrophorectic determination of phosphatases from VA mycorrhizal roots. Z Pflanzernähr Bodenkd 152:261-265.

Gianinazzi S, Gianinazzi-Pearson V, Dexheimer J. 1979. Enzymatic studies on the metabolism of vesicular-arbuscular mycorrhiza. III. Ultrastructural localization of acid and alkaline phosphatase in onion roots infected by Glomus mosseae (Nicol. \& Gerd.). New Phytol 82: 127-132.

Gianinazzi-Pearson V, Gianinazzi S. 1976. Enzymatic studies on the metabolism of vesicular-arbuscular mycorrhiza. I. Effect of mycorrhiza formation and phosphorus nutrition on soluble phosphatase activities in onion roots. Physiol Vég 14:833-841.

1978. Enzymatic studies on the metabolism of vesicular-arbuscular mycorrhiza. II. Soluble alkaline phosphatase specific to mycorrhizal infection in onion roots. Physiol Pl Pathol 12:45-53.

- - 1983 . The physiology of vesicular-arbuscular mycorrhizal roots. Pl Soil 71:197-209.

, Smith SE, Gianinazzi S, Smith FA. 1991. Enzymatic studies on the metabolism of vesicular-arbuscular mycorrhizas. V. Is $\mathrm{H}^{+}$-ATPase a component of ATP-hydrolysing enzyme activities in plant-fungus interface? New Phytol 117:61-74.

Guillemin JP, Orozco MO, Gianinazzi-Pearson V, Gianinazzi S. 1995. Influence of phosphate fertilization on fungal alkaline phosphatase and succinate dehydrogenase activities in arbuscular mycorrhiza of soybean and pineapple. Agri Ecosyst Environ 53:63-69.

Hansa JG, Laporta M, Kuna MA, Reimschuessel R, Hulett FM. 1981. A soluble alkaline phosphatase EC 3.1.3.1 from Bacillus licheniformis MC14. Histochemical localization purification characterization and comparison with the membrane associated alkaline phosphatase. Biochim Biophys Acta 657:390-401.
Jeanmaire C, Dexheimer J, Marx C, Gianinazzi S, Gianinazzi-Pearson V. 1985. Effect of vesicular-arbuscular mycorrhizal infection on the distribution of neutral phosphate activities in root cortical cells. J Pl Physiol 119: 285-293.

Klemperer FW, Miller JM, Hill CJ. 1949. The inhibition of alkaline phosphatase by beryllium. J Biol Chem 180 : 281-288.

Kojima T, Hayatsu M, Saito M. 1998. Intraradical hyphae phosphatase of the arbuscular mycorrhizal fungus $\mathrm{Gi}$ gaspora margarita. Biol Fertility Soils 26:331-335.

Larsen J, Thingstrup I, Jacobsen I, Rosendahl S. 1996. Benomyl inhibits phosphorus transport but not fungal alkaline phosphatase activity in a Glomus-cucmber symbiosis. New Phytol 132:127-133.

Lowry OH, Rosebrough NJ, Farr AL, Randal RJ. 1951. Protein measurement with the Folin phenol reagent. J Biol Chem 193:265-275.

Macdonald RM, Lewis M. 1978. The occurrence of some acid phosphatases and dehydrogenases in the vesiculararbuscular mycorrhizal fungus Glomus mosseae. New Phytol 80:135-141.

McArthur DAJ, Knowles NR. 1993. Influence of vesiculararbuscular mycorrhizal fungi on the response of potato to phosphorus deficiency. Pl Physiol 101:147-160.

Reid TW, Wilson IB. 1971. E. coli alkaline phosphatase. Enzymes 3rd ed. 4:373-415.

Saito M. 1995. Enzyme activities of the internal hyphae and germinated spores of an arbuscular mycorrhizal fungus Gigaspora margarita Becker \& Hall. New Phytol 129: 425-431.

Say JC, Furriel RP, Ciancaglini P, Jorge JA, Lourdes M, Polizeli TM, Pizauro JM, Terenzi HF, Leone FA. 1996. Conidial alkaline phosphatase from Neurospora crassa. Phytochemistry 41:71-75.

Scandalios JG. 1969. Genetic control of multiple molecular forms of enzymes in plants: a review. Biochem Genet 3:37-79.

Schubert A, Wyss P, Wiemken A. 1992. Occurrence of trehalose in vesicular-arbuscular mycorrhizal fungi and in mycorrhizal roots. J Pl Physiol 140:41-45.

Shachar-Hill Y, Pfeffer PE, Douds D, Osman SF, Doner LW, Ratcliffe RG. 1995. Partitioning of intermediary carbon metabolism in vesicular-arbuscular mycorrhizal leek. Plant Physiol 108:7-15.

Smith SE, Read DJ. 1997. Mycorrhizal symbiosis. 2nd ed. San Diego, California: Academic Press. 605 p.

Solaiman MZ, Saito M. 1997. Use of sugars by intraradical hyphae of arbuscular mycorrhizal fungi revealed by radiorespirometry. New Phytol 136:533-538.

Taussky HH, Shorr E. 1953. A microcolorimetric method for the determination of inorganic phosphorus. J Biol Chem 202:675-685.

Thomas M, Aldridge WN. 1966. The inhibition of enzymes by beryllium. Biochem J 98:94-99.

Tisserant B, Gianinazzi-Pearson V, Gianinazzi S, Gollote A. 1993. In planta histochemical staining of fungal alkaline phosphatase activity for analysis of efficient arbuscular mycorrhizal infections. Mycol Res 97:245-250.

Wilkinson GN. 1961. Statisitcal estimation in enzyme kinetics. Biochem J 80:324-332. 